\title{
Une antique tradition chez les hommes de tribu des hauts-plateaux yéménites : la culture du sorgho
}

Geneviève Bédoucha

\section{(2) OpenEdition \\ 12 Journals}

Édition électronique

URL : https://journals.openedition.org/tc/881

DOI : $10.4000 /$ tc. 881

ISSN : 1952-420X

Éditeur

Éditions de l'EHESS

\section{Édition imprimée}

Date de publication : 1 février 1987

ISSN : 0248-6016

\section{Référence électronique}

Geneviève Bédoucha, "Une antique tradition chez les hommes de tribu des hauts-plateaux yéménites : la culture du sorgho », Techniques \& Culture [En ligne], 8 | 1987, mis en ligne le 23 janvier 2006, consulté le 29 septembre 2022. URL : http://journals.openedition.org/tc/881 ; DOI : https://doi.org/ $10.4000 /$ tc. 881

Ce document a été généré automatiquement le 29 septembre 2022.

Tous droits réservés 
Une antique tradition chez les hommes de tribu des hauts-plateaux yéménites : la culture du sorgho

Geneviève Bédoucha 